\title{
Factors Effecting Discoloration and Carbonization of Unmanufactured Flue-cured Tobacco *
}

\author{
by B. S. Holt, Jr., D. M. Chilton and J. A. Sampson \\ Universal Leaf Tobacco Co., Inc., Richmond, Virginia, U.S.A.
}

\section{SUMMARY}

Modern advances in the mechanical processing of unmanufactured tobacco have developed conditions which could be favorable for the discoloration, carbonization, and possible pyrogenic reaction of flue-cured tobacco. Severe carbonization has been found in fluecured tobaccos with moisture, packed temperature, and packed densities as low as $11 \%, 40{ }^{\circ} \mathrm{C}$, and $370 \mathrm{~kg} / \mathrm{m}^{3}$ respectively, and sugar contents as low as $14 \%$ (moisture-free basis). We have focused our investigation on the redrying, prizing, and storage processes. The parameters chosen for this study included moisture content, packed temperature and packed density, and the insulative effects of packing containers as well as the effect of row position in storage. Data from the redrying and prizing processes were recorded for each container of tobacco. The tobacco temperature was monitored every four hours for the first $\mathbf{7 2}$ hours after packing and periodically thereafter when conditions so indicated. Samples for color comparison and chemical analysis were taken at the beginning of each test, after 72 hours in storage and later as necessary. Key factors identified were packed density, moisture content and sustained internal temperature. A model for carbonization is proposed and an extension is made for the pyrogenic reaction.

\section{ZUSAMMENFASSUNG}

Die bei der maschinellen Bearbeitung von Rohtabak heutzutage angewandten fortschrittlichen Verfahren können bei Virginia-Tabak die Entwicklung von Verfärbungs- und Verkohlungsprozessen sowie möglicherweise pyrogene Reaktionen fördern. Starke Verkohlung von Virginia-Tabak wurde unter folgenden milden Bedingungen beobachtet: Feuchtigkeitsgehalt: $11 \%$, Packungstemperatur: $40^{\circ} \mathrm{C}$, Packungsdichte:

\footnotetext{
* Receired: 29th March 1985 -. accepted: 8th August 1985.
}

$370 \mathrm{~kg} / \mathrm{m}^{3}$, Zuckergehalt: $14 \%$ (auf Trockenbasis). Die vorliegende Untersuchung befaßt sich mit den Trocknungs-, Verpackungs- und Lagerungsvorgängen, wobei folgende Parameter ausgewählt wurden: Feuchtigkeitsgehalt, Packungstemperatur, Packungsdichte, Isolierwirkung des Verpackungsmaterials sowie der Einfluß des Standortes bei der Lagerung. Die Zustandsdaten wurden während des Trocknungs- und Verpackungsvorganges für jeden Tabakbehälter einzeln erhoben. Die Tabaktemperatur wurde im Laufe der ersten 72 Stunden nach der Verpackung alle vier Stunden und danach je nach den Umständen in gleichmäßigen Zeitabständen gemessen. Zum Farbvergleich und für die chemische Analyse wurden Proben zu Beginn jeder Untersuchung, nach 72stündiger Lagerung und danach soweit erforderlich entnommen. Als wichtigste Einflußgrößen erwiesen sich die Packungsdichte, der Feuchtigkeitsgehalt und die sich im Innern des Behälters aufbauende Temperatur. Für den Verkohlungsprozeß wird unter Einbeziehung der pyrogenen Reaktion ein Modell vorgeschlagen.

\section{RESUME}

Dans le cas du tabac de Virginie, les méthodes modernes mises en cuvre aujourd'hui pour le traitement mécanique du tabac brut peuvent créer des conditions propres à favoriser la décoloration et la carbonisation ainsi que d'éventuelles réactions de pyrogénation. Une forte carbonisation du tabac de Virginie a été observée dans les conditions modérées suivantes: taux d'humidité: $11 \%$, température de l'unité de traitement: $40^{\circ} \mathrm{C}$, densité apparente: $370 \mathrm{~kg} / \mathrm{m}^{3}$, teneur en sucre: $14 \%$ (ramenée à la matière sèche). La présente étude porte sur les opérations de séchage, d'emballage et de stockage, les paramètres choisis étant le taux d'humidité, la température de l'unité de traitement, la densité apparente, l'effet isolant du matériau d'emballage ainsi que l'influence de la rangée de stockage. Les différentes valeurs ont été relevées séparément pour chacune des caisses contenant le tabac pendant 
Table 1.

Factory conditions.

\begin{tabular}{l|c|c|c|c|c|c|c}
\hline Grade & $\begin{array}{c}\text { Green } \\
\text { input } \\
(\mathrm{kg} / \mathrm{h})\end{array}$ & $\begin{array}{c}\text { Redried } \\
\text { output } \\
(\mathrm{kg} / \mathrm{h})\end{array}$ & $\begin{array}{c}\text { Green } \\
\text { input } \\
\text { moisture } \\
(\%)\end{array}$ & $\begin{array}{c}\text { Redried } \\
\text { output } \\
\text { moisture } \\
(\%)\end{array}$ & $\begin{array}{c}\text { Reducing } \\
\text { sugar } \\
(\%)\end{array}$ & $\begin{array}{c}\text { Packed } \\
\text { temperature } \\
\left({ }^{\circ} \mathrm{C}\right)\end{array}$ & $\begin{array}{c}\text { Packed } \\
\text { density } \\
\left(\mathrm{kg} / \mathrm{m}^{3}\right)\end{array}$ \\
\hline "A (bodied) & 10,780 & 7,625 & 19.7 & 12.6 & 16.8 & 42.2 & 370 \\
"B (bodied) & 11,510 & 8,355 & 20.5 & 12.9 & 17.0 & 42.8 & 370 \\
C (bodied) & 9,365 & 6,470 & 16.0 & 12.4 & 11.6 & 38.3 & 370 \\
D (bodied) & 10,015 & 6,990 & 17.8 & 12.5 & 16.8 & 40.0 & 370 \\
E (bodied) & 10,045 & 7,050 & 16.7 & 12.6 & 17.0 & 39.4 & 370 \\
F (thin) & 10,640 & 7,110 & 19.0 & 13.1 & 14.0 & 40.5 & 370 \\
G (bodied) & 10,775 & 7,865 & 21.6 & 13.2 & 17.0 & 40.5 & 370 \\
\hline
\end{tabular}

"Denotes carbonized tobaccos.

Note: Molsture test results are based on the 16-hour Hearson steam oven method. Sugar results are on a moisture-free basis.

Table 2.

Packed temperature and molsture tests.

\begin{tabular}{c|c|c}
\hline $\begin{array}{c}\text { Packed } \\
\text { temperature } \\
\left({ }^{\circ} \mathrm{C}\right)\end{array}$ & $\begin{array}{c}\text { Temperature } \\
\text { range } \\
\text { (high/low) } \\
\text { ("C) }\end{array}$ & $\begin{array}{c}\text { Packed } \\
\text { moisture } \\
(\%)\end{array}$ \\
\hline 41.1 & $45.6 / 38.3$ & 13.2 \\
42.2 & $46.1 / 39.4$ & 13.3 \\
42.2 & $48.3 / 41.7$ & 13.7 \\
42.8 & $46.1 / 39.4$ & 13.4 \\
42.8 & $48.3 / 41.1$ & 13.4 \\
$* 42.8$ & $47.8 / 41.1$ & 12.9 \\
$* 42.8$ & $48.9 / 41.7$ & 13.0 \\
43.3 & $47.8 / 40.6$ & 14.1 \\
43.3 & $49.4 / 42.8$ & 13.9 \\
43.9 & $48.3 / 42.2$ & 14.3 \\
44.4 & $48.3 / 41.1$ & 12.2 \\
$* 44.4$ & $48.9 / 41.1$ & 12.1 \\
44.4 & $48.9 / 41.1$ & 12.7 \\
45.0 & $47.8 / 41.7$ & 12.4 \\
45.0 & $49.4 / 42.2$ & 13.3 \\
45.6 & $48.3 / 40.6$ & 12.0 \\
45.6 & $49.4 / 41.7$ & 12.1 \\
46.1 & $48.3 / 41.1$ & 11.9 \\
\hline & & \\
\hline & &
\end{tabular}

Table 3.

Packed density tests.

\begin{tabular}{c|c|c}
\hline $\begin{array}{c}\text { Density } \\
\left(\mathrm{kg} / \mathrm{m}^{3}\right)\end{array}$ & $\begin{array}{c}\text { Packed } \\
\text { temperature } \\
\left({ }^{\circ} \mathrm{C}\right)\end{array}$ & $\begin{array}{c}\text { Temperature } \\
\text { range } \\
\text { (high/low) } \\
\left({ }^{\circ} \mathrm{C}\right)\end{array}$ \\
\hline 370 & 40.6 & $48.3 / 41.7$ \\
370 & 40.6 & $48.9 / 42.2$ \\
370 & 41.1 & $47.8 / 41.1$ \\
385 & 41.1 & $47.8 / 41.1$ \\
385 & 41.1 & $49.4 / 43.3$ \\
385 & 41.7 & $49.4 / 43.3$ \\
400 & 42.2 & $49.4 / 43.9$ \\
400 & 42.8 & $49.4 / 43.3$ \\
$* 400$ & 42.8 & $50.6 / 44.4$ \\
$* 417$ & 42.8 & $50.0 / 43.9$ \\
417 & 43.3 & $47.2 / 41.1$ \\
417 & 43.3 & $47.8 / 42.8$ \\
433 & 42.8 & $47.8 / 41.7$ \\
433 & 44.4 & $48.9 / 42.2$ \\
433 & 45.0 & $47.8 / 42.2$ \\
433 & 46.7 & $48.9 / 42.8$ \\
433 & 46.7 & $50.0 / 44.4$ \\
433 & 47.2 & $48.3 / 42.8$ \\
\hline & &
\end{tabular}

* Denotes staining.

High: temperature increase from packed temperature to peak temperature 16-20 hours after packing.

Low: temperature decrease from peak temperature to final temperature 72 hours after packing.

Moisture test results are based on the 16 -hour Hearson steam oven method. 
les opérations de séchage et d'emballage. La température du tabac a été notée toutes les 4 heures au cours des 72 premières heures suivant l'emballage, puis, selon les conditions, 3 intervalles de temps réguliers. En vue de la comparaison des couleurs et de l'analyse chimique, des échantillons ont été prélevés au début de chaque examen, à l'issue de $\mathbf{7 2}$ heures de stockage et, par la suite, dans la mesure où cela s'avérait nécessaire. La densité apparente, le taux d'humidité et la température s'établissant à l'intérieur de la caisse se sont révélés des facteurs-clefs. On propose d'étendre le modèle de carbonisation retenu au processus de pyrogénation.

\section{INTRODUCTION}

Unpublished reports of severely discolored and carbonized flue-cured tobaccos have surfaced in recent years from the United States of America and other tobacco growing countries. These experiences have yielded much information about the effects of various processing techniques which can result in the discoloration and carbonization of tobacco. The wide acceptance of the corrugated case has changed packing conditions significantly, but has inadvertently created a set of conditions which in some circumstances can contribute to the carbonization of flue-cured tobacco (1-7). This paper is a study of the conditions that exist during the processing and storage of unmanufactured flue-cured tobacco, and will try to determine the factors responsible for carbonization.

For the purpose of this paper, we define carbonization as an exothermic reaction which occurs in a package of redried flue-cured tobacco, resulting in blackening or caramelization of the tobacco (2). Completely carbonized tobacco has no commercial value and is unfit for future use.

\section{CARBONIZATION OF UNITED STATES FLUE-CURED TOBACCO}

Over five years ago, in late August, quantities of South Carolina and Eastern Carolina flue-cured strip tobaccos were found to have become carbonized following processing and storage at a United States processing plant. These tobaccos were purchased at auction in the South Carolina and Eastern Carolina belts and were predominantly from the middle stalk position. The tobaccos were purchased and shipped in burlap sheets to a green prizing plant where the tobacco was compressed into bulk bales with a net weight of approximately 635 kilograms and a packed density of about 400 kilograms per cubic meter. The bales were wrapped in $13 \mu \mathrm{m}$ plastic film and then shipped to a stemmery where they were held in temporary storage for a short period prior to processing.

The tobaccos were removed from storage and placed in a vacuum moisture conditioning system at a steam temperature of $38-46^{\circ} \mathrm{C}$. After moisture conditioning, the tobacco was introduced directly into the threshing process through a bulking conveyor, and was not subjected to electronic or manual searching. Bypassing the searching process caused the tobacco to enter the thresher at a higher temperature with a higher moisture content than tobacco which has passed through the searching process. The redried strip products were packed in two-piece full telescope corrugated cases with inside dimensions of $106.7 \mathrm{~cm}$ long $\times 73.3 \mathrm{~cm}$ wide $\times 69.2 \mathrm{~cm}$ high, and a volume of 0.542 cubic meter. The tobacco was packed at a net weight of $200 \mathrm{ki}-$ lograms, at a density of 370 kilograms per cubic meter. The packed temperature ranged from $40^{\circ} \mathrm{C}$ to $45^{\circ} \mathrm{C}$ with a weighted average of $42{ }^{\circ} \mathrm{C}$. The oven volatiles of the redried product ranged from $12.0 \%$ to $14.4 \%$ with a weighted average of $12.8 \%$ as measured in a Hearson steam oven for 16 hours at $100^{\circ} \mathrm{C}$. The reducing sugar content of these tobaccos averaged $16.9 \%$ (moisturefree basis).

After the tobacco was packed, it was moved directly to a storage warehouse of standard metal clad, concrete floor construction. The building lacked adequate ventilation since it was filled to capacity during August, the entrance doors were closed, and all the joints in the building were sealed with vinyl plastic to prepare the storage for fumigation.

Identical grades of tobacco were processed at two different stemmeries at approximately the same time; however, carbonization occurred at only one location. In addition, a grade of lower stalk "thin" tobacco with a lower reducing sugar content but otherwise the same was run at both processing plants during the same period with no damage. Measurements made during the processing of the carbonized and non-carbonized tobaccos are shown in Table 1.

Analyzing the production and handling data as well as the properties of the tobaccos processed, we were able to identify several factors which were most likely responsible for the carbonization:

1. High sugar content of over $14.0 \%$ (moisture-free basis);

2. High green lamina moisture content;

3. High redryer output of over $7,600 \mathrm{~kg} / \mathrm{h}$;

4. High packed temperature;

5. Inadequate storage ventilation, and the position of the cases stacked within the rows of the storage building;

6. An average ambient temperature of $27^{\circ} \mathrm{C}$ during the period and an average relative humidity of $88.6 \%$.

A review of the records of the affected grades revealed that these tobaccos were packed in hogsheads until 1977, thereafter the tobaccos were packed in corrugated cases. As a result, the product is now being packed at a $9 \%$ higher density in a material having a $75 \%$ lower heat transfer coefficient (8). 


\section{FACTORY EXPERIMENTS}

We have attempted to recreate the conditions which existed and carbonize redried flue-cured tobacco in one of our factories. Guided by experiences and research and analysis of our earlier work, we selected a midstalk grade from the 1983 U.S. flue-cured crop for our tests. Since reducing sugar levels were generally lower in the 1983 U.S. crop, we also used a mid-stalk, high sugar grade from the 1983 Canadian flue-cured crop. The variables for these tests were: packed temperature, packed moisture, packed density, and packaging material. The tests were run under actual processing conditions at our stemmeries in Wilson, North Carolina, and Simcoe, Ontario, Canada. Each test series was limited to three replications per set of test conditions. In all tests except the packaging material tests, tobacco was packed in corrugated cases whose heat transfer coefficient was $3.7 \mathrm{~W} / \mathrm{m}^{2}{ }^{\circ} \mathrm{C}(9)$.

\section{PACKED MOISTURE AND TEMPERATURE TESTS}

Tobacco was packed at various moisture contents and various packed temperatures for this series of experiments. Samples for moisture analysis were taken by the thief method from each case packed and tested by the 16-hour Hearson steam oven method, with the results corrected for temperature, latitude, and barometric pressure. The packed temperatures were determined at the prize room test station with an Alnor pyrometer with a type $J$ thermocouple, and in storage with a type $\mathrm{J}$ thermocouple inserted in the center of the tobacco cake. Product temperature in storage was recorded every four hours for the first $\mathbf{7 2}$ hours after packing. In the Canadian tests, the cases were held in the scrap room where ambient temperatures of about $36^{\circ} \mathrm{C}$ could be maintained.

During each test run, a sample of tobacco was taken from the product stream and reserved for color comparison. At the end of the 72-hour test period, representative samples were taken from the test cases and compared to the control sample. The control sample was held throughout these tests so a direct comparison could be made in case of a delayed reaction in a particular case of tobacco.

Due to the mechanics of the redrying process, it is generally true that as packed moisture increases, packed temperature decreases. As expected, our tests showed that there is a direct correlation between the increase in moisture content and the degree of increase in the packed temperature during storage (Table 2).

\section{PACKED DENSITY TESTS}

Test tobacco was packed at densities ranging from 370 to $\mathbf{4 3 0}$ kilograms per cubic meter in corrugated cases of moderate thermal conductance. Packed temperature was a secondary variable in this test. Our tests show that tobacco packed at a relatively low density and packed temperature reached about the same peak temperature $16-20$ hours after packing as did tobacco packed at high density and temperature (Table 3).

\section{PACKAGING MATERIAL TEST'S}

In the packaging material study, we examined the contribution of different materials and designs to the heat buildup inside the tobacco cake. In addition to a plywood container, we chose a corrugated container with the lowest heat transfer coefficient, thus providing the widest range of values for our tests. In order to provide a control test, tobacco was packed in a wire-bound plywood case and transported to a storage warehouse where the case material was easily removed.

Corrugated cases have between 3.75 to 4.5 times the insulating power of plywood used in hogsheads and wooden cases. Our tests indicate that the internal temperature of tobacco packed in corrugated cases is $0.5-$ $1{ }^{\circ} \mathrm{C}$ higher after four hours in storage as compared to plywood and no container. After 72 hours, the temperature of tobacco packed in corrugated cases averaged $2{ }^{\circ} \mathrm{C}$ higher than that of tobacco packed in plywood cases. Although some discoloration was noted in the factory test samples, we did not observe any instances of true carbonization.

\section{CONCLUSIONS}

With the earlier introduction of high capacity strip redryers, corrugated packaging material, and higher packed densities and redried moistures, the industry created a set of conditions which increase the chances for carbonization of redried flue-cured tobacco. We have determined that carbonization can occur under a unique set of circumstances where each of the following conditions are present to some extent:

1. Leaf density: "Bodied" tobaccos from the middle and upper stalk positions have higher leaf density and reducing sugar content than "thin" or lower stalk tobaccos, and appear to be much more susceptible to carbonization.

2. Sugar content: Tobacco with a high sugar content tends to scorch easily. Reducing sugars react with amino acids in tobacco releasing heat and promoting the pyrogenic reaction:

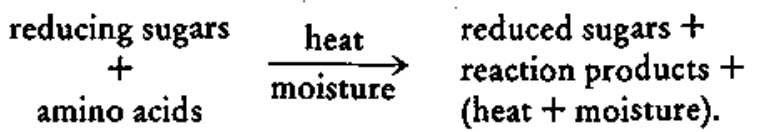

As the reaction proceeds, the heat generated inside the case of tobacco increases, and the tobacco may eventually begin to smolder and char. 
3. Green moisture: Tobacco which is highly compressed in green prized bales $\left(400 \mathrm{~kg} / \mathrm{m}^{3}\right)$, requires more vacuum conditioning than tobacco in sheets so the tobacco can be loosened for feeding and transporting through the system. Also, higher heat and steam are needed in the ordering drums so that the tobacco can be opened and threshed properly.

4. Redryer performance: In extremely hot weather, drying of tobacco is easier, therefore facilitating higher production output. Hot atmospheric conditions reduce heat losses of tobacco in the ordering sections, which means that chamber temperatures will be higher than normal. At higher temperatures, there is lower relative humidity and lower vapor pressure in the chambers, and more steam must be added so the tobacco will order properly. The effect of this is to raise the temperature of the tobacco even more.

5. Packed temperatures: It is believed that scorching occurs when the temperature of the tobacco reaches $54-57^{\circ} \mathrm{C}$. Our tests show that there is a gradual increase in packed temperature for 16-20 hours after packing. High packed temperatures can result in sufficient heat buildup inside a case of tobacco to trigger a pyrogenic reaction.

6. Packed density: Tobacco packed at a higher density tends to cool at a slightly slower rate than tobacco packed at a lower density. The tobacco packed at a higher density may also be unevenly distributed throughout the case. At high packed temperatures, these areas of very high tobacco density may provide "hot spots" where the conditions for carbonization are ideal.

7. Packaging material: Corrugated cases have four times the insulating power of the plywood used in hogsheads and wooden cases. The corrugations have air spaces which provide insulation, and tobacco packed in corrugated cases cools at a much slower rate than tobacco packed in plywood.
8. Storage conditions: The combination of a large quantity of tobacco packed in corrugated cases at high temperature and density, stacked in an unventilated storage building during hot weather caused a buildup of heat in the cases stored in the center of the rows. There were instances where the cases on the ends of the rows were in excellent condition, while adjacent cases stored in the center of the row were found to have carbonized.

\section{REFERENCES}

1. Fryd, C. F. M., and P. R. Kiff: The determination of moisture in tobacco; Analyst 76 (1951) 25-32.

2. Dixon, L. F.: Flue-cured tobacco - Natural aging of flue-cured cigarette tobaccos; Ind. Eng. Chem. 28 (1936) 180-189.

3. Akehurst, B. C.: Tobacco, 2nd edition, Longman, London and New York, 1981.

4. Samfield, M.: The storage and ageing of tobacco; Tob. Int. 176, 21 (1974) 29-32.

5. Samfield, M.: The moisture content of tobacco, Part I; Tob. Int. 176, 3 (1974) 21-23.

6. Samfield, M.: The moisture content of tobacco, Part II: The effect of moisture on the processing of tobacco for cigarette manufacturing; Tob. Int. 176, 5 (1974) 44-46.

7. Samfield; M.: The moisture content of tobacco, Part III; Tob. Int. 176, 8 (1974) 22-24.

8. American Plywood Association: Applications Summary, 1981, 13.

9. Patelka, J.: Compressive strength theory; Report to Union Camp Co., 1976.

Authors'address:

Universal Leaf Tobacco Co., P. O. Box No. 25099

Hamilton Street at Broad,

Ricbmond, Virginia, 23260, U.S.A. 